\title{
KEGIATAN PERAWATAN DAN PENGENALAN WISATA SITUS SEJARAH PADA ZAMAN KOLONIAL MAKAM DINGER DI DESA TULUNGREJO KECAMATAN BUMIAJI KOTA BATU
}

\author{
Moch. Nurfahrul Lukmanul Khakim*, Dhimas Dandy Nugraha Ramadhan, Farah Dhieba \\ Firman, Yutris Sindi Kurnia Putri \\ moch.nurfahrul.fis@um.ac.id
}

Jurusan Sejarah, Fakultas IImu Sosial, Universitas Negeri Malang

6 Februari 2020, Diterbitkan 30 April 2020

\begin{abstract}
Abstrak
Makam Dinger merupakan bangunan cagar yang berlokasi di Kota Batu, Jawa Timur. Tujuan kegiatan pengabdian ini adalah untuk memperkenalkan situs sejarah yang ada di Kota Batu supaya lebih dikenal oleh masyarakat. Metode yang dilakukan adalah observasi, ekplorasi ide, perancangan, dan pelaksanaan kegiatan. Pihak yang terlibat dalam kegiatan ini adalah RT setempat, perwakilan karang taruna setempat, mahasiswa UM jurusan sejarah Fakultas IImu Sosial. Hasil dari kegiatan ini berupa perawatan situs sejarah dan pemasangan papan informasi yang berisi tetang sejarah singkat serta informasi mengenai Makam Dinger. Adanya papan informasi ini dapat membuat masyarakat setempat maupun orang yang berkunjung ke Makam Dinger mendapatkan pengetahuan terkait sejarah Makam Dinger.
\end{abstract}

Kata Kunci: Perawatan, Pengenalan, Makam Dinger, Kota Batu

\section{PENDAHULUAN}

Indonesia adalah negara dengan sejarah yang panjang. Seperti yang diketahui bersama bahwa Indonesia pernah disinggahi oleh negara lain, seperti Portugis, Inggris, Spanyol, Belanda, dan Jepang. Dahulu Indonesia terkenal dengan kekayaan rempah-rempah nya yang banyak sehingga menarik minat bangsa barat untuk mencarinya ke Indonesia (Ricklefs, 2008). Di antara beberapa negara tersebut yang paling lama singgah di Indonesia adalah Belanda. Tercatat hampir 350 tahun Belanda singgah di Indonesia. 350 tahun tentu bukan waktu yang singkat, di mana pada masa tersebut Indonesia banyak sekali mengalami penderitaan. Keberadaan Belanda di Indonesia telah memberikan banyak perubahan di berbagai aspek kehidupan meliputi aspek ekonomi, politik, sosial, dan budaya.

Hingga saat ini masyarakat indonesia masih dapat menemui sisa-sisa peninggalan Belanda yang tersebar luas di seluruh wilayah Indonesia. Di beberapa wilayah tentunya peninggalan tersebut cukup dikenal karena ukurannya yang besar, letaknya yang strategis, maupun kisah di balik bangunan tersebut. Akan tetapi banyak pula peninggalan Belanda yang tidak diketahui oleh masyarakat. Penyebabnya adalah karena tempatnya yang berada di tengah hutan, atau karena peninggalan tersebut berukuran yang kecil sehingga tidak begitu mendapatkan perhatian masyarakat.

Bahkan banyak pula warga Belanda yang memilih tinggal dan menetap di Indonesia karena para warga Belanda ini sudah nyaman dan mudah mencari nafkah di Indonesia. Para warga Belanda memiliki kedudukan yang tinggi di Indonesia sehingga wajar warga Belanda ini memiliki pengaruh di beberapa daerah di Indonesia, salah satunya wilayah Kota Batu Jawa Timur. Di daerah Batu terdapat sebuah makam yang diduga milik seorang hartawan Belanda yang cukup terkenal dan sangat kaya pada zaman dahulu yaitu Graaf J. Dinger.

$\mathrm{Di}$ tengah-tengah area perkebunan di daerah Bumiaji, Batu terdapat Sebuah Bangunan yang tampak tua yang diketahui bernama Makam Dinger. Bangunan ini nampak mencolok sendiri di 
tengah hijaunya kebun dan dinginnya hawa di area sekitar makam tersebut. Namun sangat disayangkan keadaan dari Makam Dinger yang merupakan salah satu peninggalan Belanda ini tidak terawat dan cenderung diabaikan baik oleh warga sekitar maupun dari desa terkait. Meskipun makam ini sebenarnya memiliki nilai sejarah, saat ini Makam Dinger hanya difungsikan sebagi tempat penunjang kegiatan warga yaitu digunakan sebagai tempat penyimpanan peralatan untuk prosesi kematian warga sekitar (Gustria \& Supriono, 2018).

\section{METODE}

Metode pengabdian antara lain. Observasi lapangan dilakukan untuk mengamati secara langsung kondisi Makam Dinger. Eksplorasi ide berupa menemukan solusi untuk melestarikan Makam Dinger. Diskusi melibatkan antara anggota kelompok, dosen pembimbing, dan ketua RT setempat. Perancangan yang terdiri dari kegiatan menuangkan ide hasil eksplorasi ke dalam wujud kegiatan pembuatan papan dan pembersihan kawasan sekitar makam. Pelaksanaan kegiatan merupakan proses dilaksanakannya kegiatan praksis sosial yaitu pembuatan papan informasi tentang situs sejarah Makam Dinger yang berlokasi di Desa Tulungrejo Kecamatan Bumiaji Kota Batu.

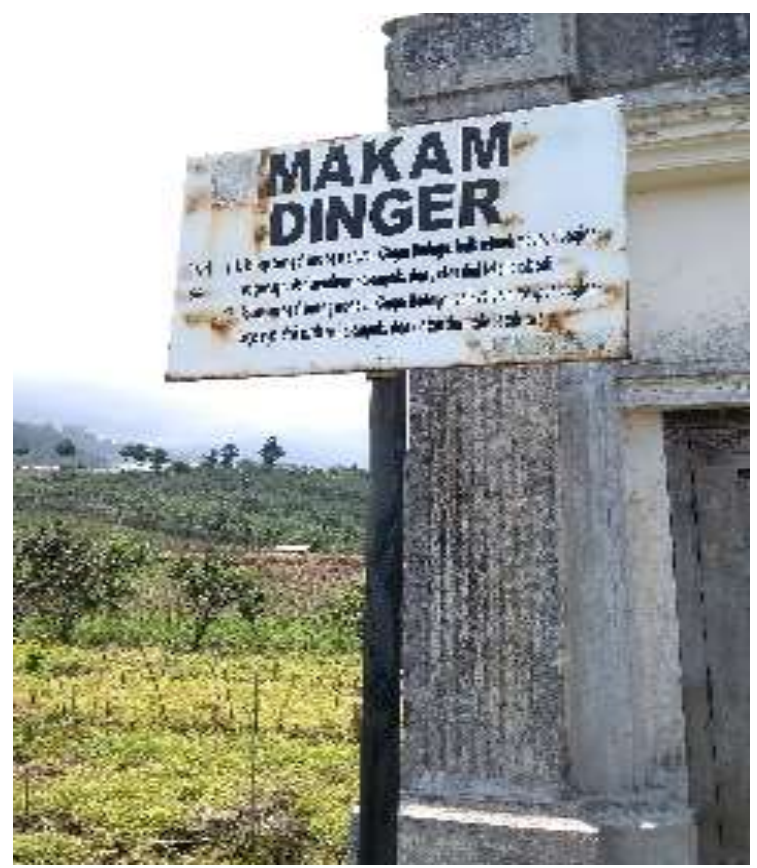

Gambar 1. Observasi ke Makam Dinger

(Sumber: Dokumentasi pribadi)

Sasaran dari kegiatan ini adalah bangunan situs sejarah masa kolonial Makam Dinger dan para warga sekitar serta wisatawan yang akan berkunjung ke Kota Batu. Diharapkan setelah adanya kegiatan ini, masyarakat dapat terbuka hatinya untuk bersama-sama dengan pemerintah setempat membersihkan serta merawat situs sejarah Makam Dinger ini agar ke depannya situs ini dapat menjadi salah satu objek wisata sejarah yang menarik banyak pengunjung.

Untuk menyelesaikan permasalah yang telah dipaparkan bada bagian pendahuluan di atas dan untuk mendukung keberlangsungan program pengabdian masyarakat ini, maka penulis mengajukan kerangka pemecahan masalah yang terdiri dari lima hal. Pertama, Tim Pengabdian Masyarakat melakukan pembentukan susunan tim yang akan melakukan pengabdian, yaitu satu orang ketua pelaksana, satu orang bendahara, satu orang sekeretaris, dan dua orang sie lapangan yang merangkap sebagai sie dokumentasi. Kedua adalah seluruh tim melakukan survei ke tempat sasaran, yang dalam hal ini adalah situs sejarah masa kolonial Makam Dinger yang terada di Desa Tulungrejo Kecamatan Bumiaji Kota Batu, Jawa Timur.

Rencana ketiga adalah persiapan pelaksanaan kegiatan pengabdian masyarakat yang dilakukan secara menyeluruh, terutama yang menyangkut penunjang kegiatan, seperti peralatan kebersihan dan juga segala hal yang terkait kegiatan pengabdian masyarakat ini. Selanjutnya adalah tim melaksanakan kegiatan pengabdian diawali dengan kegiatan pembersihan jalan menuju lokasi yang banyak ditumbuhi rumput liar. Selanjutnya adalah dengan membersihkan tembok 
bangunan yang dipenuhi dengan lumut dan beberapa coretan-coretan. Kegiatan dilanjutkan dengan menyapu bagian sekitar lokasi bangunan.

Kegiatan selanjutnya adalah evaluasi kegiatan pengabdian masyarakat yang dilakukan dengan mewawancarai warga sekitar bangunan ataupun pengunjung yang berada di lokasi bangunan. Evaluasi meliputi perbandingan antara keadaan bangunan sebelum adanya kegiatan ini dan keadaan bangunan setelah adanya kegiatan pengabdian ini. Evaluasi bertujuan untuk mengetahui pencapaian hasil kegiatan pengabdian masyarakat; untuk mengetahui efektivitas proses kegiatan pengabdian; serta untuk mengetahui kesalahan apa yang terjadi selama kegiatan berlangsung sehingga dapat memeperbaikinya dan dapat digunakan sebagai acuan pada kegiatan selanjutnya.

Beberapa faktor pendukung yang sangat menentukan keberhasilan kegiatan pengabdian masyarakat ini adalah: mahasiswa yang bertanggung jawab, di mana di setiap bagian menjalankan tugasnya dengan baik dan senantiasa bergotong royong dalam melakukan kegiatan ini; adanya peran aktif teman-teman di luar tim yang dengan ikhlas mendukung kegiatan ini sepenuhnya dari awal hingga akhir; faktor pendukung selanjutnya adalah dosen pengampu yang tanpa rasa berat hati selalu membimbing dan membantu mengarahkan segala hal yang terkait kegiatan ini dengan sangat baik. Faktor pendukung yang ketiga adalah partisipasi dan peran aktif masyarakat sekitar. Dan faktor pendukung yang terakhir adalah fasilitas kegiatan yang sudah cukup baik, dari mulai transportasi yang memadai, sarana penunjang kegiatan yang tidak kurang satu apapun. Dengan beberapa fator pendukung di atas diharapkan kegiatan pengabdian masyarakat ini diharapkan dapat berjalan dengan lancar hingga kegiatan selesai nanti dan mungkin suatu saat nanti kegiatan ini dapat terus berjalan.

\section{HASIL DAN PEMBAHASAN}

Kebersihan lingkungan adalah sebuah manifestasi bagi setiap individu dalam menjaga kesehatan yang sangat penting dalam kehidupan sehari-hari. Kebersihan lingkungan adalah suatu kondisi yang bebas dari segala kotoran dan penyakit, yang bisa merugikan segala bidang yang berkaitan dengan kegiatan dan perilaku lingkungan masyarakat, di mana kehidupan manusia tidak bisa dipisahkan baik lingkungan sosial maupun lingkungan alam (Buhungo, 2012). Kebersihan lingkungan biasanya dilakukan dengan berbagai cara, seperti membuang sampah pada tempatnya, menyingkirkan benda-benda yang tidak tepat, dan lain-lain.

Situs mempunyai berbagai pengertian yang berbeda, situs dalam dimensi komputer atau internet memiliki pengertian yang berbeda dengan situs dalam dimensi sejarah. Menurut Na'am (2019:31) makam adalah tempat persemayaman manusia yang telah wafat baik pada sebelum maupun sesudah masuknya pengaruh Islam dan biasanya dianggap keramat oleh sebagian masyarakat Jawa. Menutur William Haviland dalam (Warsito, 2012) mengatakan bahwa situs sejarah merupakan tempat-tempat dimana ditemukan bukti-bukti tinggalan arkeologi di kediaman makhluk manusia pada zaman dahulu. Situs biasanya ditemukan berdasarkan kajian di suatu daerah. Ada beberapa upaya yang dapat dilakukan untuk melestarikan situs bangunan bersejarah, antara lain: (1) Memelihara peninggalan sejarah dengan sungguh-sungguh, menjaga kebersihan dan keindahan; (2) Melestarikan peninggalan sejarah tersebut agar tidak rusak, baik oleh faktor alam maupun karena ulah manusia; (3) Tidak vandalisme/mencorat-coret benda peninggalan sejarah; (4) Aktif menjaga kebersihan dan keutuhan; (5) Wajib mematuhi tata tertib yang ada dalam setiap tempat peninggalan sejarah; serta (6) Wajib mematuhi peraturan pemerintah dan tata tertib yang berlaku.

Selain itu Juniawandahlan (2017), berpendapat terdapat beberapa cara untuk melestarikan situs sejarah dalam bentuk bangunan terutama makam, yaitu sebagai berikut: (1) Merawat kebersihan dan kerapian makam, misalnya mebersihkan makan dari tumbuh-tumbuhan liar; (2) Mencegah dari kerusakan-kerusakan karena alam, misalnya karena pelapukan, jamur, dan genangan air; (3) Mencegah dari ulah tangan jahil manusia, misalnya coret-coret, merusak bangunan makam, dan lain-lain.

Kota Batu merupakan salah satu kota yang cukup lama didiami oleh bangsa Belanda pada saat era kolonialisme Indonesia. Hal ini tentu saja menyebabkan Kota Batu memiliki banyak tempat yang merupakan peninggalan bangsa Belanda. Beberapa bangunan cukup jelas dan masih berdiri kokoh hingga saat ini dan ada beberapa bangunan bersejarah lain yang tidak terawat dan jauh dari kata terawat. Diantara bangunan-bangunan tersebut terdapat salah satu bangunan yang tampaknya cukup tua dan berada di tengah-tengah area perkebunan di daerah Bumiaji, Kota Batu (Permana, 2016). Bangunan bersejarah yang memiliki nama Makam Dinger ini terlihat menonjol karena letaknya yang berada di tengah-tengah area perkebunan warga. 
Bangunan bersejarah ini dahulunya adalah makam milik keluarga Dinger. Hal ini berdasarkan bukti yang ada yaitu berupa pahatan pada bagian atas pintu makam, yang bertuliskan "Graf Familie Dinger". Bahasa Belanda itu bermakna makam keluarga Dinger. Di sebelah kanan dan kiri pahatan terdapat sebuah tulisan anno 1917 yang berarti tahun 1917 yang menandakan bahwa bangunan tersebut dibangun pada tahun tersebut. Berdasarkan data dari Laporan Inventarisasi Kota Batu (2014) diterangkan bahwa makam ini pada zaman dulu dipakai untuk menyimpan peti mati milik Graaf J. Dinger dan istrinya. Graaf J. Dinger adalah direktur dari bank Excompto, seorang administrator, dan seorang tuan tanah dari beberapa perkebunan kopi, teh, kina, dan tebu. Graaf J. Dinger lahir di Amsterdam pada 16 Agustus 1853 dan meninggal pada 2 Maret 1917 di desa Tulungrejo. Dinger memiliki seorang istri yang bernama Elisabeth Malvine Ernestine van Polanen Petel yang meninggal beberapa puluh tahun setelah kematian Dinger, yaitu pada 7 Maret 1938 . Ketika masih hidup, Dinger berpesan kepada anaknya yang bernama Rutger Dinger untuk dimakamkan di salah satu lahan perkebunan miliknya.

Pada zaman kolonial bangunan ini memiliki kondisi yang baik dan indah. Bangunan utama makam ini dikelilingi kolam. Oleh karena itu, pada jalan masuk menuju ke bangunan utama terdapat sebuah jembatan yang walaupun pada saat ini di sekitar bangunan tersebut tidak ditemukan sungai atau danau (Permana, 2016). Keindahan bangunan ini tentunya tidak berjalan hingga sekarang, meskipun makam ini telah ditetapkan sebagai cagar budaya oleh pemerintah. Makam Dinger ini tampak terlupakan dan kurang terawat dengan banyakya sampah yang dibuang sembarangan di sekitar lokasi serta coretan-coretan pada beberapa badan bangunan.

Capaian implementasi pengabdian ini diawali dengan pembuatan surat izin melalui kantor jurusan Sejarah UM langsung kepada ketua jurusan untuk mendapat dukungan moral dan administrasi. Kegiatan selanjutnya, tim pengabdian melakukan koordinasi dengan pihak pengelola bangunan terkait waktu pelaksanaan kegiatan, tempat kegiatan, dan sarana pendukung yang sekiranya dibutuhkan akan disediakan oleh pihak pengelola. Koordinasi ini dilakukan melalui pertemuan langsung oleh ketua pelaksana pengabdian dengan perwakilan dari pihak pengelola bangunan.

Pengabdian dilaksanakan di situs sejarah Makam Dinger yang bertempat di desa Tulungrejo Kecamatan Bumiaji Kota Batu. Waktu kegiatan dilaksanakan dua kali disebabkan cuaca yang tidak menentu, sehingga tim penyelenggara menyediakan watu dua kali untuk berjaga-jaga. Adapun pelaksanaan pengabdian dilakukan dua kali, yaitu tahap pertama yaitu pada tanggal 17 Maret 2019 . Capaian tahap pertama yaitu perawatan dengan membersihkan rumput dan sampah di sekitar area Makam Dinger. Tahap kedua, tanggal 24 Maret 2019. Capaian tahap kedua adalah melakukan edukasi dengan pengelola situs sejarah dan masyarakat sekitar mengenai sejarah Makam Dinger.

Peserta yang berpartisipasi dalam kegiatan ini adalah lima orang mahasiswa dan dosen Jurusan Sejarah Universitas Negeri Malang. Jumlah peserta ini dibatasi sebanyak lima orang disebabkan pendistribusian mahasiswa untuk melakukan kegiatan pengabdian di tempat lain. Walaupun demikian kegiatan diharapkan tetap berjalan dengan semestinya dan sesuai dengan target yang ingin dicapai.

Pengabdian diawali dengan persiapan pelaksanaan kegiatan pengabdian masyarakat yang dilakukan secara menyeluruh, terutama yang menyangkut penunjang kegiatan, seperti peralatan kebersihan dan juga segala hal yang terkait kegiatan pengabdian masyarakat ini. Selanjutnya adalah tim melaksanakan kegiatan pengabdian diawali dengan kegiatan pembersihan jalan menuju lokasi yang banyak ditumbuhi rumput liar. Selanjutnya adalah dengan membersihkan tembok bangunan yang dipenuhi dengan lumut dan beberapa coretan-coretan. Kegiatan dilanjutkan dengan menyapu bagian sekitar lokasi bangunan.

Kegiatan selanjutnya adalah evaluasi kegiatan pengabdian masyarakat yang dilakukan dengan mewawancarai warga sekitar bangunan ataupun pengunjung yang berada di lokasi bangunan. Evaluasi meliputi perbandingan antara keadaan bangunan sebelum adanya kegiatan ini dan keadaan bangunan setelah adanya kegiatan pengabdian ini. Evaluasi bertujuan untuk mengetahui pencapaian hasil kegiatan pengabdian masyarakat; untuk mengetahui efektivitas proses kegiatan pengabdian; serta untuk mengetahui kesalahan apa yang terjadi selama kegiatan berlangsung sehingga dapat memeperbaikinya dan dapat digunakan sebagai acuan pada kegiatan selanjutnya.

Setelah diadakannya evaluasi maka puncak dari kegiatan ini adalah pengunggahan video kegiatan pengabdian masyarakat ke media sosial YouTube. Hal ini dilaksanakan untuk edukasi dan menarik minat masyarakat untuk ikut serta bersama pihak pengelola bangunan menjaga dan merawat situs sejarah Makam Dinger supaya selalu lestari dan terhindar dari kehancuran akibat termakan oleh waktu. Edukasi sejarah yang relevan dengan fakta penting untuk membangun kesadaran sejarah pada masyarakat (Khakim, 2018). 
Salah satu indikator tercapainya tujuan dan manfaat kegiatan pengabdian masyarakat ini adalah adanya kenaikan jumlah wisatawan yang berkunjung ke situs sejarah Makam Dinger. Minat masyarakat sekitar untuk merawat bangunan bersejarah yang ada di daerahnya, bukan untuk digunakan sebagai tempat yang tidak seharusnya. Keterlibatan pemerintah dan masyarakat penting dalam menjaga situs sejarah/kawasa wisata sejarah (Khakim, Ulfa, Putri, \& Budi, 2019). Diharapkan dengan adanya kegiatan ini bangunan-bangunan lama yang bernasib sama seperti Makam Dinger dapat dimanfaatkan dengan baik. Masyarakat dan pemerintah terus merawat makam Dinger sehingga ke depannya bangunan bersejarah seperti ini dapat dipelajari dan dijaga oleh para penerus bangsa.

\section{KESIMPULAN}

Kegiatan pengabdian masyarakat dilaksanakan di sebuah situs bangunan bersejarah masa kolonial yaitu Makam Dinger, bertempat di Desa Tulungrejo Kecamatan Bumiaji Kota Batu. Bangunan ini dahulunya adalah makam milik keluarga Dinger, didalamnya tersimpan peti mati Graaf J. Dinger dan istrinya; seorang hartawan Belanda yang sangat berpengaruh pada masanya. Pemilihan tempat didasarkan pada kepeduliaan dan kehawatiran anggota tim akan situs sejarah yang terlupakan sehingga keadaannya pun sudah memprihatinkan, bahkan tak banyak orang mengetahuinya. Bangunan yang dahulunya elok nan indah dengan jembatan yang mengantarkan ke bangunan utama serta di bawahnya terdapat kolam yang mengelilinya, meskipun saat ini sudah tertutup dan tidak lagi dapat dijumpai.

Bila berkunjung ke Makam Dinger saat ini, hanya didapati bangunan yang tak terawat, ditumbuhi rumput-rumput liar dan sampah berserakan dimana-mana. Badan bangunan yang dipenuhi dengan coret-coretan dan lumut menambah kesan tak terurus pada bangunan. Keindahannya luntur seakan-akan bangunan yang hilang identitasnya. Melihat kondisi tersebut, anggota tim tergerak untuk melaksanakan kegiatan pengabdian masyarakat sesuai dengan tahapan rancangan kegiatan yang telah ditentukan mulai dari tahap awal sampai tahap akhir yaitu evaluasi kegiatan. Dibentuk pula susunan tim agar setiap anggota dapat bekerja sesuai tugas dan kewajiban dengan sebaik-baiknya. Sasaran dan tujuan kegiatan ini dapat tercapai dengan maksimal serta membawa manfaat baik bagi anggota tim dan tentunya kepada warga sekitar. Dengan memanfaatkan media sosial YouTube, anggota tim bermaksud mengenalkan situs sejarah Makam Dinger dan mengingatkan pentingnya menjaga aset-aset sejarah di sekitar kita agar tidak punah karena ketidakpedulian dan rasa acuh tak acuh masyarakatnya sendiri.

\section{DAFTAR PUSTAKA}

Buhungo, R. A. (2012). Faktor perilaku Kesehatan Masyarakat dan Kondisi Lingkungan Rumah Dengan Kejadian Malaria. Jurnal Health and Sport. Vol. 5, No. 2.

Gustria, D. D., \& Supriono. (2018). Analisis Potensi Situs Peninggalan Makam Dinger Sebagai Wlsata Budaya di Kota Batu. Jurnal Administrasi Bisnis (JAB), Hal. hlm. 66-74.

Juniawandahlan. (2017, Januari 31). Menjaga, Merawat, dan Melestarikan Peninggalan Sejarah, (Online), (https://kebudayaan.kemdikbud.go.id/mkn/menjaga-merawat-dan-melestarikanpeninggalan-sejarah/), diakses pada 27 Februari 2019.

Khakim, M. N. L. (2018). Kesadaran Sejarah Dalam Novel 'Menunggu Beduk Berbunyi' Hamka ( 1950 ) Sebagai Pengembangan Materi Ajar Sejarah Indonesia Modern. Vol. 1, No. 2, HIm. 163-175. https://doi.org/http://dx.doi.org/10.17977/um033v1i22018p163.

Khakim, M. N. L., Ulfa, M., Putri, U., \& Budi, N. A. (2019). Urgensi Pengelolaan Pariwisata Kampung Heritage. Jurnal Teori Dan Praksis Pembelajaran IPS, Vol. 4, No.1, hlm. 15-22. https://doi.org/http://dx.doi.org/10.17977/um022v4i12019p015.

Laporan Inventarisasi Kota Batu. 2014. Makam Dinger, kuburan tak bertuan peninggalan meneer Belanda, (Online), (https://kebudayaan.kemdikbud.go.id/bpcbjatim/misteri-makam-familiegraaf-j-dinger/) diakses pada 27 Februari 2019.

Naam, Muh. Fakhrudin. 2019. Pertemuan Antara Hindu, Cina, dan Islam pada Ornamen Masjid dan Makam Mantingan Jepara. Yogyakarta: Samudra Biru.

Permana, R. W. (2016, November 17). Makam DInger, kuburan tak bertuan peninggalan meneer Belanda, (Online), (https://m.merdeka.com/malang/pariwisata/makam-dinger-kuburan-takbertuan-peninggalan-meneer-belanda-161116d.html) diakses pada 27 Februari 2019

Ricklefs, M. C. 2008. Sejarah Indonesia Modern 1200 - 2008. Jakarta: Serambi

Warsito. (2012). Antropologi Budaya. Yogyakarta: Penerbit Ombak. 